\title{
A truly refractory crucible from fourth millennium Tepe Hissar, Northeast Iran
}

\author{
Christopher P. Thornton ${ }^{\mathrm{a}, *}$, Thilo Rehren ${ }^{\mathrm{b}}$ \\ a Department of Anthropology, University of Pennsylvania, Philadelphia, PA 19104, USA \\ ${ }^{\mathrm{b}}$ UCL Institute of Archaeology, London, WC1H OPY, UK
}

\section{A R T I C L E I N F O}

\section{Article history:}

Received 9 December 2008

Received in revised form

2 July 2009

Accepted 31 August 2009

\section{Keywords:}

Crucible

Steatite

Arsenical copper

Lead

Chalcolithic

Tepe Hissar

Iran

\begin{abstract}
A B S T R A C T
From the Early Chalcolithic to the Late Iron Age, melting and smelting crucibles were usually made from non-refractory ceramic fabrics, which required heating of the charge from within the crucible to avoid collapsing the ceramic itself. In this paper, an unusual melting crucible from Northeast Iran, radiocarbondated to the Late Chalcolithic (ca. 3600 BCE), will be presented that significantly changes our understanding of the development of technical ceramics in Southwest Asia. This crucible, made of a highly refractory talc-based ceramic held together by an outer layer of traditional non-refractory ceramic, is to our knowledge unprecedented at such an early date. As will be argued, this ancient crucible was heated from the exterior or from below and not from the interior. This method of firing, combined with the highly-specialized construction technique, makes this crucible so far unique in prehistoric metallurgy, and forces us to re-examine traditional models for the development of technical ceramics and metallurgical practices in the Old World.
\end{abstract}

(C) 2009 Elsevier Ltd. All rights reserved.

\section{Introduction}

The literature on ancient metallurgy is dominated by studies in which finished artefacts are subjected to chemical, isotopic, and microscopic examinations. While these projects provide a wealth of information on early metallurgical practices, finished artefacts are only part of the story. Less 'attractive' remains of ancient metalworking practices, such as slag and technical ceramics, are often ignored. This is unfortunate as there is much more to be learned about early metallurgy by analyzing all stages in the process, from ore beneficiation to smelting to processing to working and finally to consumption and deposition (Ottaway and Roberts, 2008).

It is important to remember that metal is not the only material being manipulated and utilized in metallurgical practices. Indeed, technical ceramics (i.e., furnaces, crucibles, moulds, etc.), lithic and groundstone tools, fuel sources, and moulds in various materials are all products of technologies that need to be understood in order to reconstruct ancient metalworking. As Lamberg-Karlovsky (1974: 338) has written in response to linear models on the origins of metallurgy: "To ignore the importance of related crafts or industries in the development of any one tends to further exaggerate the individual 'jumps' within one craft, thereby strengthening the

\footnotetext{
* Corresponding author. Tel.: +1 2158930474.

E-mail addresses: cpt2@sas.upenn.edu (C.P. Thornton), th.rehren@ucl.ac.uk (Th. Rehren).
}

concept of [technological] 'stages'." Far better are "cross-craft" or "multi-craft" approaches, in which different technologies are analyzed in tandem in order to provide a more nuanced understanding of ancient craft production in its socio-cultural context (see McGovern and Notis, 1989; Shimada, 1996, 2007; Miller, 2007).

The study of ancient technical ceramics is inherently a 'crosscraft' exercise as it involves analysis of the ceramic in addition to analysis of adhering slag and metallic prills. Furthermore, while the analyst of technical ceramics requires knowledge about ceramic production and behaviour at high temperatures, the end goal of the ancient craftsperson was metallurgical in nature. Thus, the decisions made in the production of the technical ceramic were generally based on what was best for the metal process, not the ceramic itself. Indeed, it is our impression that most early crucibles were destroyed in the process and almost always discarded after very few use cycles, if not after each use (Rehren, 2003; Bayley and Rehren, 2007).

The 'sacrificial' nature of most early technical ceramics has led many researchers to dismiss them as 'crude', thereby suggesting that ancient craftspeople had little interest in or understanding of the material properties of the clay and ceramics in general. While this may have been the case in certain situations, there are always exceptions. In this paper, the recent analysis of an unusual (and so far unique) metalworking crucible from the prehistoric site of Tepe Hissar in Northeast Iran is presented (Fig. 1). Securely dated to the middle of the 4th millennium BCE, this crucible, which was apparently used for the melting and alloying of arsenical copper 


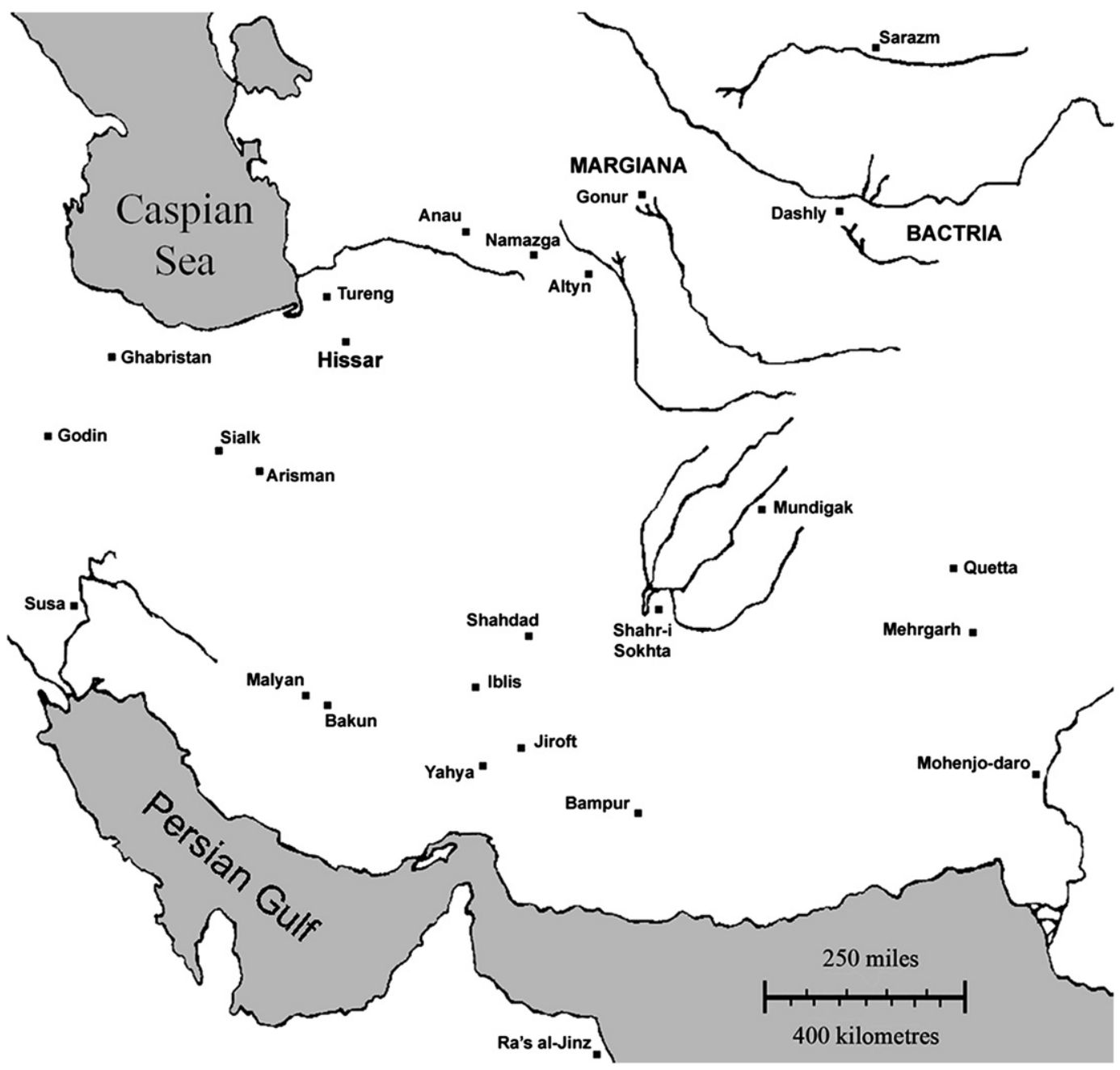

Fig. 1. Map of archaeological sites in Iran and neighboring regions showing the location of Tepe Hissar.

with lead, combines a normal technical ceramic with a truly refractory ceramic consisting predominantly of crushed steatite. For convenience, and in line with common archaeological usage, in this paper we use steatite and talc $\left(\mathrm{Mg}_{3} \mathrm{Si}_{4} \mathrm{O}_{10}(\mathrm{OH})_{2}\right)$ almost interchangeably, with talc referring to crushed steatite rock. As this paper will show, this crucible was constructed by a highly-skilled craftsperson (or craftspeople) familiar not only with the properties of different metals, but also with the properties of clay-based ceramics and fired steatite. In addition, the selective use of a specific mineral to enhance refractoriness suggests that the use of less refractory clay for other crucibles may have been a conscious choice rather than an indication of ignorance or ambivalence.

\section{Development of crucibles}

Crucibles played a central role in the development of metallurgy as containers for the high temperatures and specific atmospheric conditions necessary to drive the smelting or melting processes, as collectors for the liquid metal, and often as providers of the silicates necessary for the production of slag (Tite et al., 1990; Rehren, 2003; Bayley and Rehren, 2007). At the same time, early crucibles had to allow for certain manipulations, such as providing a controlled air flow from above using blowpipes or tuyeres, or lifting and tilting the crucible for casting. Early crucibles show a bewildering range of shapes and decorations, but all share a rather open form with their widest diameter at the mouth, a depth of typically less than the radius of the mouth, and thick, organically-tempered fabrics. From the very beginning of metallurgy until after the Late Bronze Age, metallurgical crucibles were almost exclusively fired from above (i.e., from the inside) by burning the fuel which forms part of the charge (Freestone, 1989). During smelting, this technique combined the two aspects of fuel that are required for metal reduction: i.e., as a provider of thermal energy and as a chemical reactant reducing the ore to metal. During melting, internal heating maximized heat transfer from the fuel to the metal by enabling direct contact between the two, while also providing a reducing environment to avoid excessive oxidation of the metal. Design details, such as broad handles into which sticks could be inserted to facilitate lifting and casting as in the Aegean (Oberweiler, 2005), boat-shaped crucibles from Chalcolithic Iran (Caldwell, 1968), or rocking crucibles ready to be tilted for pouring as in Egypt (Davey, 1985), add cultural flavour to the principle technology.

A major reason for the dominant use of internally-heated crucibles during the earliest phases of metallurgy was the lack of suitably-refractory ceramic materials. Heating crucibles from below, as was routinely done from the Roman period onwards, required a fabric that would maintain enough mechanical stability at temperatures in excess of $1100{ }^{\circ} \mathrm{C}$ to allow lifting without warping or breaking under the pressure of the tongs and the weight of the charge, and which would not crack under sudden thermal 
shock when removed from the fire. More refractory fabrics are often brittle, allowing cracks to propagate quickly and potentially leading to catastrophic failure of the crucibles during use. It has been argued elsewhere (Rehren, 2003; Bayley and Rehren, 2007) that a major design feature of Roman and medieval crucibles mitigating against the latter problem was to apply a less refractory ceramic to the outer surface to prevent cracks spreading too far. This less refractory ceramic provided an outer layer which was partly molten at operating temperatures and, therefore, highly viscous. Such outer layers act as an adhesive, holding together the inner vessel even in the event of severe cracking, as well as providing a thermal buffer against rapid temperature loss. In some cases, these outer layers were used to link a small mould to the mouth of the crucible, enabling casting to be done by a simple rotation of the crucible/mould package without loss through spillage or oxidation (Eckert, 1990).

Almost all early Near Eastern crucibles analyzed so far are made from the local clay used for domestic pottery, often calcareous and ferruginous, with melting temperatures at or around $1100{ }^{\circ} \mathrm{C}$ (e.g., Neuninger et al., 1964; Davey, 1988; Freestone, 1989; Tite et al., 1990; Rehren et al., 1997; Rehren, 1997; Frame, 2004). These early crucibles are typically adapted to their technical use by adding organic temper, which increases their insulating properties to maximize heat retention, and by building thick walls, which ensures sufficient mechanical strength even if the innermost layer starts to bloat and melt under the thermal impact of the fuel. These technical ceramics are therefore not based on clays selected for their refractory properties, but on specific adaptation during clay preparation. Truly refractory crucibles, based on specificallyselected white-firing kaolinitic clays, begin to emerge in the Late Iron Age, are in regular (but certainly not dominant) use during the later Roman period, and are fully developed in their technical potential only during the medieval period (Freestone, 1989; Rehren, 2003; Bayley and Rehren, 2007; Martinón-Torres et al., 2008). The exception to this is the unique crucible from Tepe Hissar presented here, which demonstrates a precocious understanding of truly refractory ceramics from the earliest period of complex metallurgy.

\section{Background to Tepe Hissar crucible}

The site of Tepe Hissar, located in Northeast Iran near the modern city of Damghan, was occupied from the late 5th to the early 2nd millennium BCE (Schmidt, 1937; Dyson and Howard, 1989). By the second half of the 4th millennium BCE, Hissar had become a major processing site for semi-precious stones such as lapis lazuli, alabaster, and carnelian, and a production site for copper-base alloys, lead, and possibly silver (Tosi, 1984, 1989). Recent analysis of the metallurgical collection from this site, which includes slag, furnace lining, crucible fragments, moulds, and finished artefacts, has demonstrated a fairly advanced technological tradition dating to the 4th millennium BCE (Thornton, 2009; Thornton et al., 2009).

The unusual refractory crucible discussed in this paper comes from the North Flat at Tepe Hissar, and was found by Dyson and Remsen (1989: 106-107) at the bottom of a $1 \times 2.5 \mathrm{~m}$ test trench dug below the western wall of a late 4 th millennium structure involved with lapis lazuli processing. The fragmentary crucible (H76-S66) was found in association with Hissar IIA painted pottery and a few early grey ware sherds in grey ash/trash deposits (Dyson pers. comm. 06/2006). Near to the crucible was found a single piece of slag (H76-S120) and some charcoal (P2619), which was radiocarbon-dated to $4830 \pm 60$ b.p. or 3737-3506 cal. BC (2- $\sigma$ ) (Dyson and Lawn, 1989; re-calibrated using Calib 5.01, InCal2004 calibration).

Five pieces of the crucible were recovered together with an additional piece of what appears to be melted ceramic. It was not possible to reconstruct the exact shape and size of the crucible as the fragments were too small, but in general it appears to have been a straight-sided or slightly globular cup with a rounded base and a rim diameter of roughly $5-10 \mathrm{~cm}$. The crucible is made of two distinct fabrics. The interior ceramic is white and powdery with a finished rim, red ochre lightly painted on the smooth exterior surface, and a thin green-grey slag adhering to the interior surface (Fig. 2). The exterior ceramic is greeny-brown, chaff-tempered and coarse with few visible mineral inclusions, and was rather crudely slapped onto the exterior surface of the white ceramic. The exterior surface of the chaffy ceramic is covered in a fleeting white plaster or clay wash.

\section{Analysis of crucible H76-S66}

One of the more complete fragments of the crucible (part of the base; sample number H76-S66a) was chosen for analysis based upon the thickness of the green slag on the interior surface

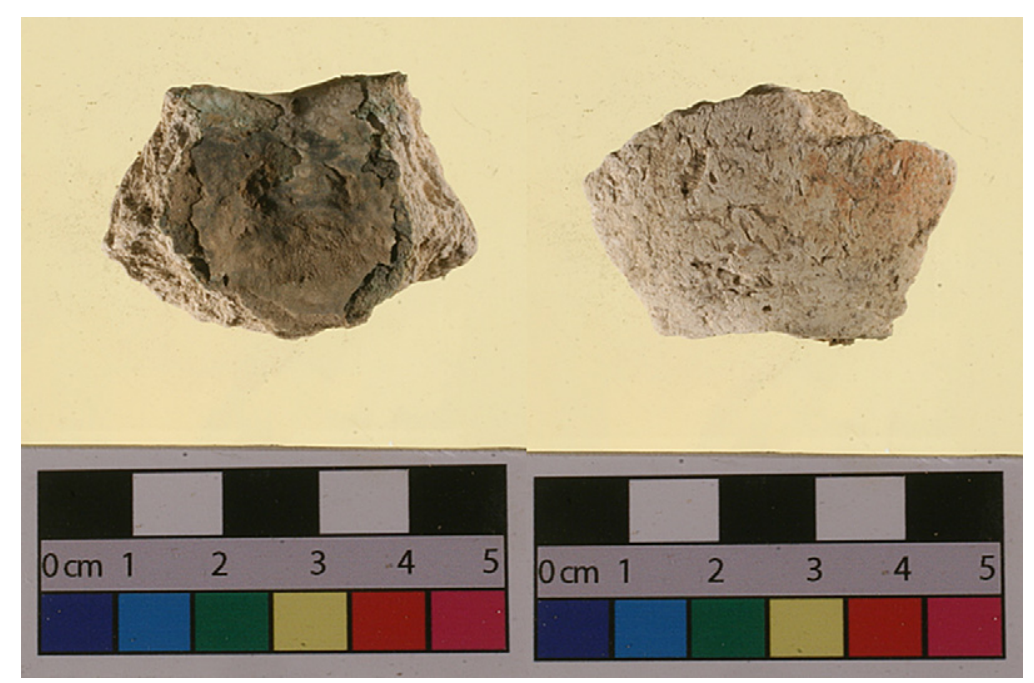

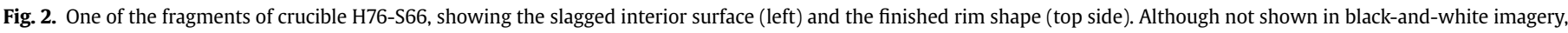

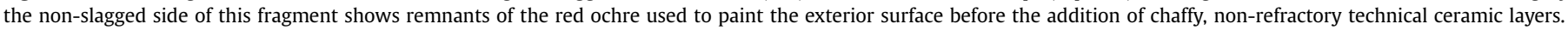


( $\sim 0.5-1 \mathrm{~mm})$ and because it represented a complete crosssection of the crucible (Fig. 3 ). The entire fragment was vacuum impregnated overnight in thin epoxy resin and then a transverse section was cut and re-mounted. The mounted sample was polished and then analyzed using a reflected light microscope for phase identification. Point-microanalyses were performed on a Philips XL 30 and a Hitachi S-3400N SEM-EDX at the Wolfson Archaeological Science Laboratories at the UCL Institute of Archaeology.

The mounted cross-section of the crucible shows the sequential arrangement of materials that make up this technical ceramic (Fig. 4). The different layers have been numbered (1-4) from interior slag to exterior white crust and will be presented in that order.

\subsection{Layer 1: crucible slag}

Analysis of the vitrified interior layer of the white ceramic revealed a glassy slag containing significant amounts of lead and copper oxide, totalling more than $20 \mathrm{wt} \%$ and indicating the metallurgical use of this vessel. The remainder of the composition is dominated by silica and magnesia with lower amounts of lime, alumina, soda, and iron oxide (see Table 1: S66a_L1). The major silicate phases in the glass are enstatite $\left(\mathrm{Mg}_{2} \mathrm{Si}_{2} \mathrm{O}_{6}\right)$ and diopside $\left(\mathrm{MgCaSi}_{2} \mathrm{O}_{6}\right)$ in a rather heterogeneous glassy matrix that fluctuates in its $\mathrm{PbO}: \mathrm{SiO}_{2}$ ratio from 1.04 to 0.27 (Fig. 5). There are a few copper prills in the slag (notably in areas with lower $\mathrm{PbO}: \mathrm{SiO}_{2}$ ratios), all bearing 1-3 wt\% arsenic and silver. Some of the prills have thin 'halos' of copper sulphide (Fig. 6).

\subsection{Layer 2a: white ceramic}

The white ceramic is quite porous with more rounded pores towards the interior surface, and many of the vacuoles appear to be left over from organic temper. There are also numerous large cracks that run from the interior to the exterior surface of the white ceramic. The ceramic is comprised of large and small angular pieces

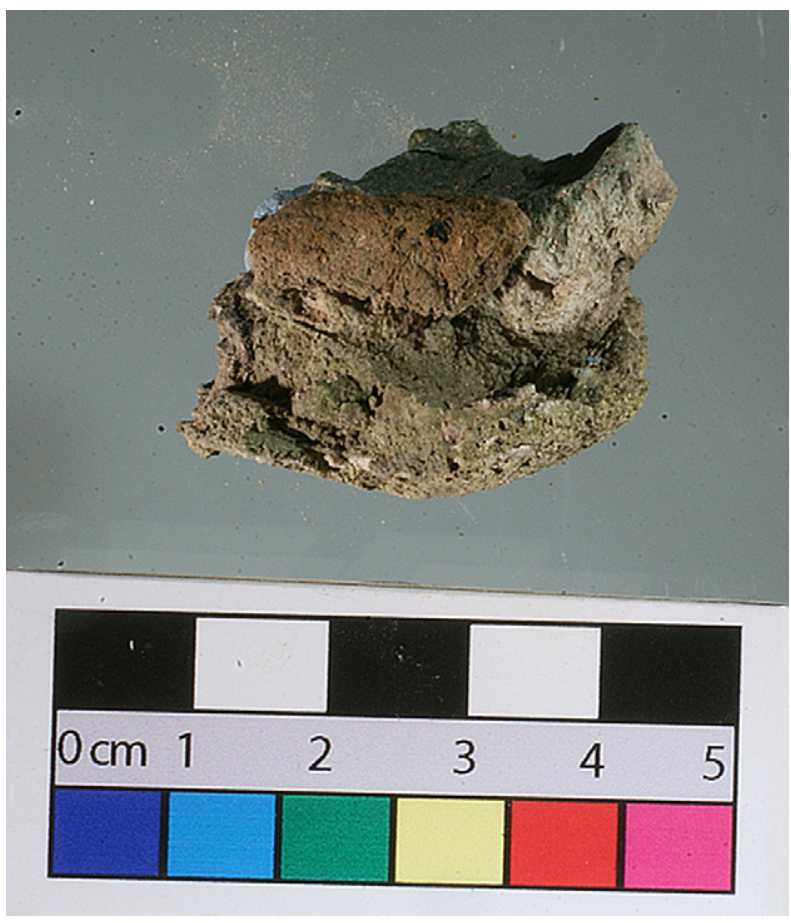

Fig. 3. Photograph of the base fragment of the crucible (H76-S66a) that was analyzed to look at the multiple layers of this complex artefact.

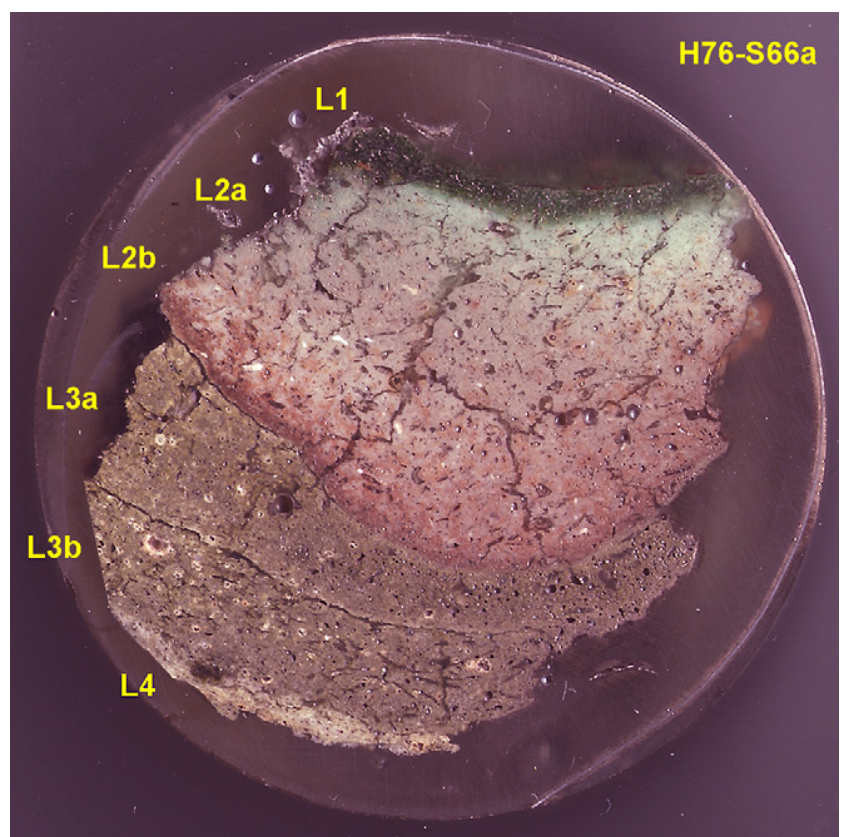

Fig. 4. The mounted cross-section of base fragment H76-S66a, showing the multiple layers (marked "L1" to "L4") of this crucible that are discussed in the text. Note in particular the thinness of the slag layer (L1) relative to the white refractory ceramic, the significant cracking of the brittle refractory ceramic (L2), and the high vitrification of the exterior chaffy ceramic layers (L3) and the white 'crust' (L4).

of talc/steatite as well as small inclusions of quartz, alkali feldspars, and titanium oxide (e.g., rutile or anatase). Its bulk composition is highly unusual for a clay-based ceramic, comprising about $62 \mathrm{wt} \%$ silica and almost $20 \mathrm{wt} \%$ magnesia, with less than $4 \mathrm{wt} \%$ alumina (Table 1: S66a_L2). Throughout the sample there are patches of lead oxide that appear to have permeated from the interior (as shown by the gradual decrease in abundance from interior to exterior), and adhering to many of the larger inclusions are small globules of lead chlorophosphate, thought to be corroded lead metal (Fig. 7). However, the overall lead oxide content of this layer remains rather limited, indicating that this is mostly contamination and not a substantial part of the material. The ceramic matrix is lower in magnesia (relative to the talc pieces) but richer in alumina, soda, and lime. The bulk composition of this layer resembles closely the composition of the slag layer, minus its lead and copper oxide content, strongly indicating that the slag layer formed from a reaction between the heavy metal oxides and the white ceramic material.

A particularly interesting inclusion in one of these cracks appears to be a piece of partially-reacted ore gangue. Its position within the ceramic matrix suggests that it entered the ceramic accidentally during the manufacture of the vessel, and does not indicate that the crucible was used for smelting ore (Fig. 8). The gangue consists of quartz and anorthoclase feldspar ((Na, $\mathrm{K}) \mathrm{AlSi}_{3} \mathrm{O}_{8}$ ) particles that have begun to react with the surrounding matrix, which is unusually rich in $\mathrm{PbO}$ relative to the normal ceramic matrix. There is a single copper prill in the gangue fragment (denoted by an arrow in Fig. 8) that contains 2-3 wt\% arsenic and silver, much like the prills in Layer 1.

\subsection{Layer $2 b$ : iron oxide on white ceramic}

The white ceramic was lightly painted with red ochre before the chaffy ceramic (Layer 3a) was placed over it. As can be seen in the mounted sample (Fig. 9), the iron oxides have permeated towards 
Table 1

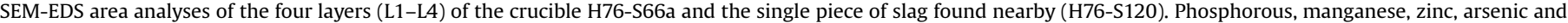
barium were not found above the detection limit of the instrument, estimated to be around $0.2 \mathrm{wt} \%$. Data normalised to $100 \mathrm{wt} \%$.

\begin{tabular}{|c|c|c|c|c|c|c|c|c|c|c|c|}
\hline Sample & $\mathrm{Na}_{2} \mathrm{O}$ & $\mathrm{MgO}$ & $\mathrm{Al}_{2} \mathrm{O}_{3}$ & $\mathrm{SiO}_{2}$ & $\mathrm{SO}_{3}$ & $\mathrm{~K}_{2} \mathrm{O}$ & $\mathrm{CaO}$ & $\mathrm{TiO}_{2}$ & $\mathrm{FeO}$ & $\mathrm{CuO}$ & $\mathrm{PbO}$ \\
\hline S66a_L1 & 2.9 & 14.1 & 2.8 & 49.2 & 0.1 & 0.8 & 5.2 & 0.0 & 1.7 & 3.7 & 18.8 \\
\hline S66a_L2 & 2.0 & 19.8 & 3.7 & 61.9 & 0.1 & 1.5 & 6.0 & 0.1 & 2.1 & 0.7 & 1.4 \\
\hline S66a_L3 & 2.5 & 2.6 & 11.8 & 58.9 & 0.2 & 2.4 & 15.2 & 0.8 & 4.8 & 0.0 & 0.6 \\
\hline S66a_L4 & 4.1 & 3.2 & 13.2 & 63.9 & 0.0 & 1.1 & 10.4 & 0.5 & 3.6 & 0.0 & 0.0 \\
\hline S120 & 0.0 & 0.8 & 5.3 & 38.0 & 0.3 & 0.5 & 2.2 & 0.1 & 50.1 & 2.7 & 0.0 \\
\hline
\end{tabular}

the middle of the white ceramic, although the greatest concentration is at the contact point between Layers $2 \mathrm{~b}$ and 3a. SEM-EDS analysis of these areas reveals only a modest change in the iron content, from 1 to $2 \mathrm{wt} \% \mathrm{FeO}$ in Layer 2a to 3-4 wt\% FeO in Layer $2 \mathrm{~b}$. This is not surprising given the strong colouring effect of red iron oxide.

\subsection{Layer 3a: interior fold of chaffy ceramic}

The interior slab of coarse, chaffy ceramic is heavily vitrified, displaying small round vesicles and large rounded vacuoles of burnt-out chaff. Numerous mineral inclusions (mainly quartz) of varying sizes are distributed irregularly throughout the ceramic, suggesting minimal working of the clay before use. The iron oxide from the outer surface of Layer $2 b$ does not seem to have penetrated Layer 3a, although in at least one area it appears to have helped the two layers to fuse together (Fig. 10). The chemical composition of this ceramic is fundamentally different from that of the white ceramic (Table 1: S66a_L3), but is the same calcareous and ferruginous alumina silicate material used consistently for technical ceramic production elsewhere on the site and typical for the wider region. As will be discussed below in more detail, it is worth noting the slightly elevated level of lead oxide in this layer ( $\sim 1 \mathrm{wt} \% \mathrm{PbO})$, which must have penetrated from the interior of the crucible if it was not present in the clay before usage.

\subsection{Layer 3b: exterior fold of chaffy ceramic}

The exterior slab of coarse, chaffy ceramic is almost identical to the interior slab. It too is heavily vitrified and contains disparate

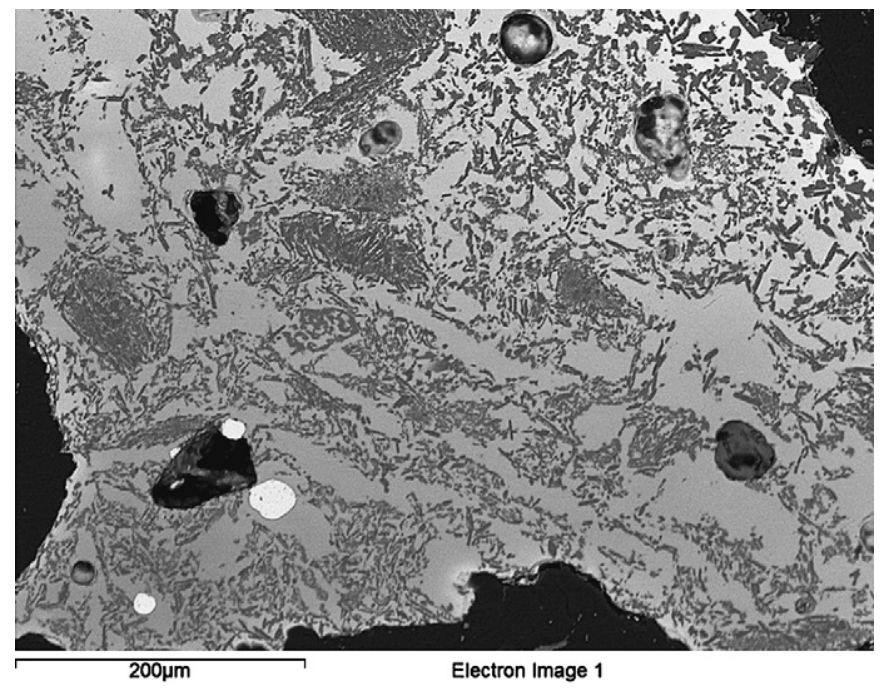

Fig. 5. Backscattered electron image of metallic prills (bright white circles) in the slag layer (L1), which consists of lathes of enstatite (darker) and diopside (lighter) in a lead oxide-rich glassy matrix (light grey areas). mineral inclusions, small rounded vesicles, and the remains of chaff tempering. The major differences are two-fold. First, this layer contains only half of the amount of lead oxide found in Layer 3a, supporting the view that lead oxide penetrated from the interior of the crucible. Second, and most importantly, the exterior surface of this layer is more vitrified than the interior surface. Indeed, certain areas at the exterior surface rich with iron (or titanium) oxide inclusions actually melted entirely, forming a vitreous material from which newly-formed Fe/Mg-pyroxenes crystallised in a glassy matrix rich in alkalis, alumina, and iron oxide (Fig. 11).

\subsection{Layer 4: white crust on exterior surface}

The exterior surface of the crucible is covered in a white, finegrained wash or crust (see Fig. 4). Chemically, Layer 4 is distinguished from Layer 3 by having significantly more soda and alumina and significantly less lime and lead oxide (Table 1: S66a_L4). Structurally, this layer is finer grained than the chafftempered ceramic and contains less mineral inclusions. It is likely that this layer is simply the remains of alumina-rich hearth material with sodium-rich plant ash that adhered to the exterior of the crucible during use. Alternatively, Layer 4 could have been a clay wash added to the chaffy ceramic to flux the exterior of the crucible.

\section{Other technical ceramics at Tepe Hissar}

This composite crucible is unique among the relatively large number of other crucible fragments excavated from the site. These other fragments provide the technological and compositional backdrop against which the quality of the crucible discussed here

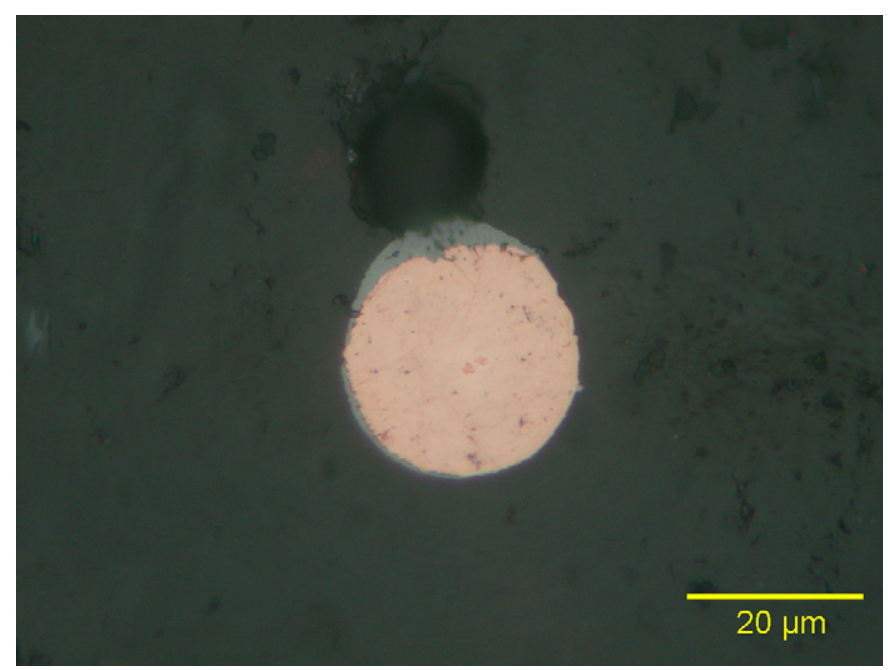

Fig. 6. One of the copper-arsenic prills in the slag layer (L1) showing the 'halo' of copper sulphide often associated with these prills. Small globules of silver are often found at the interface between the copper metal and the sulphide 'halo' $(\times 1000, \mathrm{ppl})$. 


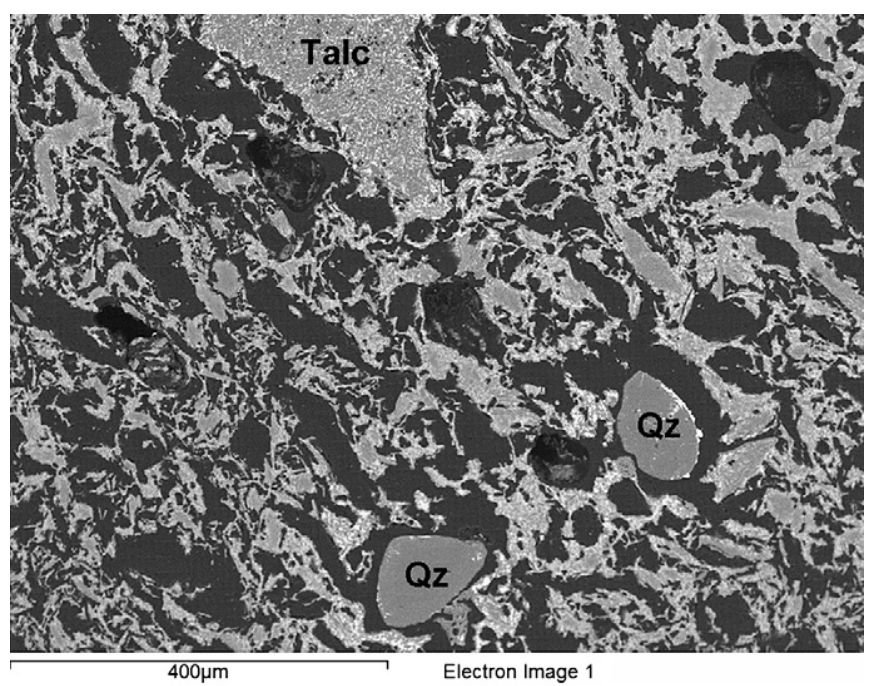

Fig. 7. Backscattered electron image of the refractory ceramic layer (L2), showing inclusions of partially-reacted quartz (' $\mathrm{Oz}$ ') and still angular fragments of crushed steatite ('Talc'). Note the bright white globules of lead, lead oxide, and lead chlorophosphate adhering to the edge of the right-hand quartz inclusion.

can be assessed. The typical technical ceramics from Tepe Hissar show little compositional variability over more than half a millennium (see Table 2). Similar to other furnace material and crucible fragments in the ancient Near East (e.g., Tite et al., 1990; Rehren et al., 1997; Veldhuijzen and Rehren, 2007), the Hissar technical ceramics are constructed of a highly calcareous and ferruginous clay with numerous inclusions of quartz, iron and titanium oxides, alkali feldspar, and apatite. Such calcareous clays are not particularly refractory due to their high lime and iron oxide content, but they were obviously sufficient for early metallurgical purposes. In fact, the non-refractory nature of such ceramics may have been beneficial to early smelting as a source of silicates for the production of slag before the advent of intentional fluxing.

Comparing the composition of the chaffy ceramic part of S66a (see Table 2: S66a_L3) with the other technical ceramics from the site, a few points are worth mentioning. First, it is obvious that the same calcareous clay was used for all of these ceramics, suggesting the continuous exploitation of a single (though somewhat variable

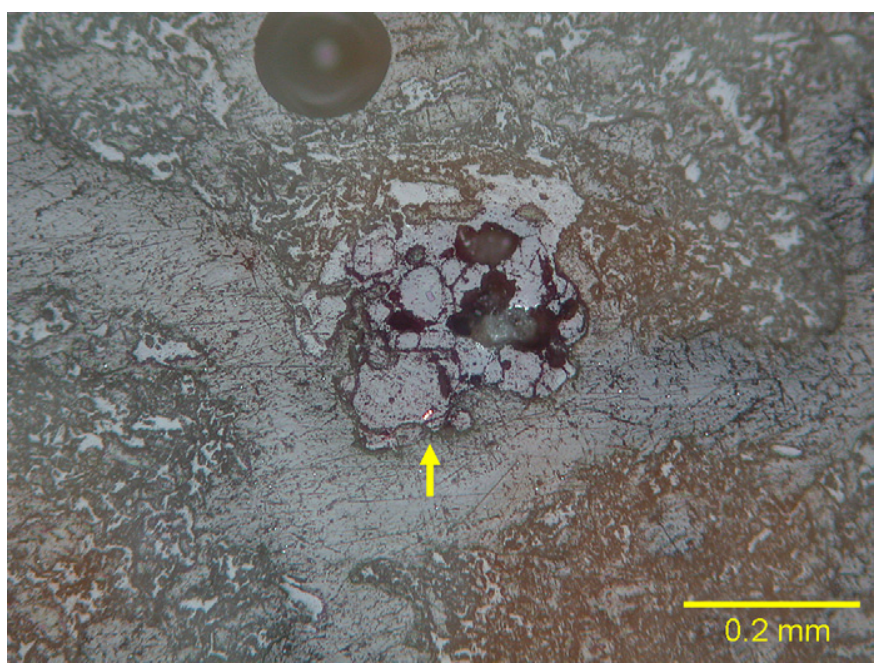

Fig. 8. An inclusion of quartz and feldspar found within the cracks of the refractory ceramic (L2). Note the small copper prill (with $2.8 \mathrm{wt} \%$ As and $2.3 \mathrm{wt} \% \mathrm{Ag}$ ) in the gangue fragment denoted by the arrow $(\times 100, \mathrm{ppl})$.

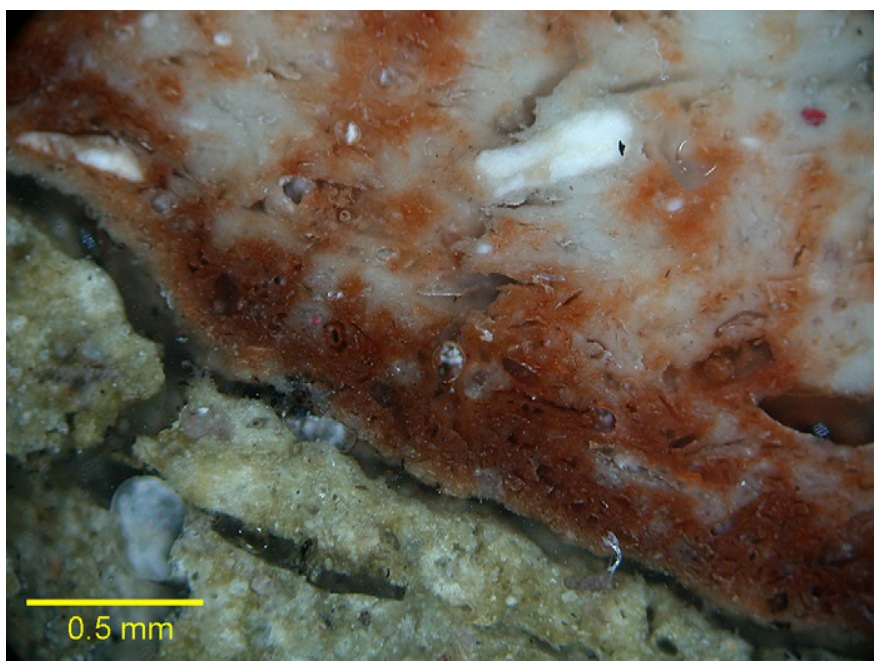

Fig. 9. The exterior surface of the white ceramic (L2b, top) and the interior slab of chaffy ceramic (L3a, bottom), showing the coloration of the white ceramic due to the addition of iron oxide. Note the intense vitrification of the non-refractory chaffy ceramic relative to the highly refractory white ceramic. The large white inclusions in the white ceramic are incompletely crushed pieces of steatite $(\times 50, x p l)$.

and most likely local) source of clay. Second, the chaffy ceramic used for S66a is slightly enriched in soda and lead oxide relative to the other chaffy technical ceramics. While the source of the lead oxide is most likely the metal charge oxidizing in the crucible and then permeating through the cracks and pores of the ceramic layers, the source of the additional soda in the S66a chaffy ceramic is less clear. Potentially, it derives from Na-rich anorthoclase inclusions found frequently in the talc-based ceramic (as suggested by the higher soda content in Layer 3a than in 3b), although a more likely alternative is the post-depositional uptake of soda during analcime formation often seen in high-fired calcareous ceramics (Schwedt et al., 2006).

\section{Analysis of H76-S120}

A single piece of slag was found together with the unusual crucible (S66) at the bottom of the test trench on the North Flat

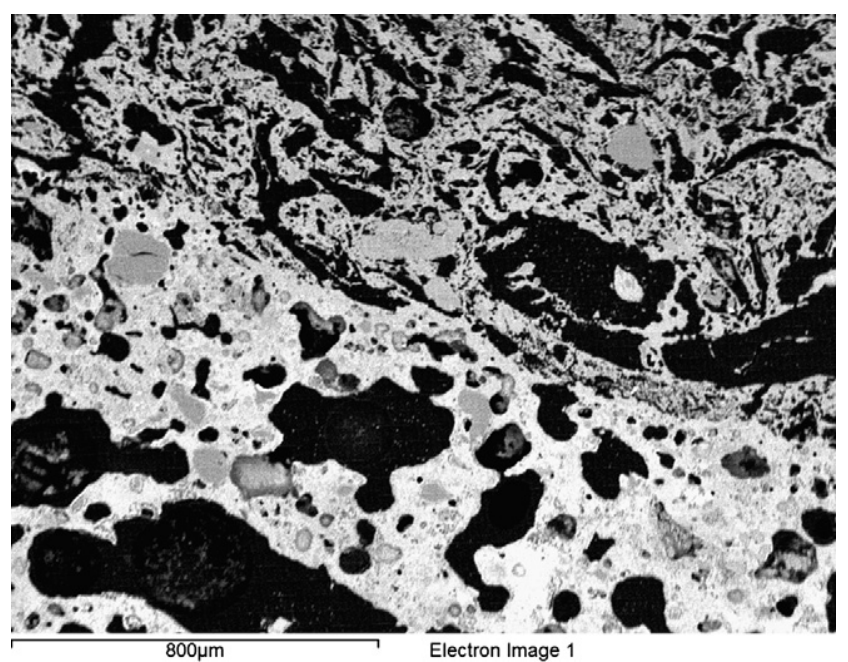

Fig. 10. Backscattered electron image of the fused interface between the vitrified chaffy ceramic layer (L3, bottom) and the more refractory talc-based ceramic (L2, top). The fusing of these two different ceramics was likely encouraged by the addition of iron oxide (L2b) to the exterior of the refractory ceramic before the addition of the chaffy ceramic layers. 


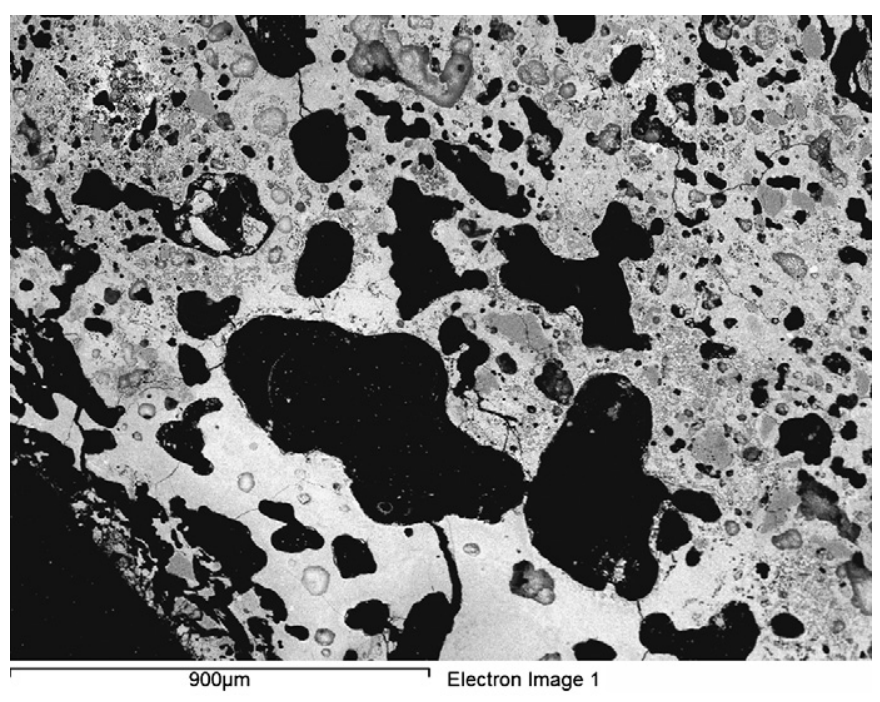

Fig. 11. Backscattered electron image showing the exterior surface of the chaffy nonrefractory ceramic (L3b) where an iron-rich inclusion has encouraged the complete vitrification of the ceramic.

(Fig. 12). A mounted sample taken from an outer edge of the upper part of the slag in the 1980s was provided by Profs. Michael Notis and Vincent Pigott for re-analysis. H76-S120 was included in this study to test its potential relationship to the metallurgical operation carried out in the crucible H76-S66, and to further understand the nature of the metallurgy represented by these finds. Bulk SEMEDX analysis of H76-S120 (see Table 1) revealed an iron-rich composition with noticeably low levels of the alkalis, alumina, and lime. This composition is quite unlike the H76-S66a slag (Layer 1), which rules out S120 originating from the crucible. However, its copper content (nearly three weight percent copper oxide) indicates that it may be linked to the source of the copper metal which was processed in the crucible.

The outer edge of the slag S120 displays dense, well-formed fayalite $\left(\mathrm{Fe}_{2} \mathrm{SiO}_{4}\right)$ crystals in a glassy matrix relatively rich in alumina, lime, and potassium oxide (Fig. 13). This zone is notable for the presence of charcoal and corroded matte prills trapped in the rapidly cooled surface layer, and for the scarcity of free iron oxide phases, such as magnetite or wüstite. It is only in the inner part of the slag (i.e., away from the reducing atmosphere created by the charcoal and where cooling proceeded more slowly) that we find well-formed magnetite crystals, often forming clusters containing numerous small prills of copper, copper-arsenic, and copper-iron matte (Fig. 14). The iron-rich bulk composition, the fayalitic matrix, the presence of sulphide prills, and the overall morphology all strongly suggest that this is smelting slag, and that the original charge for the smelt was copper or copper-arsenic ores in an iron oxide or iron (arsenic?)-sulphide gangue. In this interior zone there are long, well-formed olivine chains in a glassy matrix.

It is quite clear that slag S120 and crucible S66 were not part of the same metallurgical operation, although, perhaps, they were used by the same metalworker as indicated by their archaeological proximity. The occurrence of copper-arsenic prills in both slags potentially links the two, in that slag S120 may originate from a smelt which produced arsenical copper that was then remelted and further processed in crucible S66.

\section{Interpretation of crucible H76-S66}

Three characteristics of the crucible presented in this paper make it stand out from other technical ceramics known from
Southwest Asia: its complex multi-layer structure; the unusual composition of the white ceramic; and the fact that it was heated from the outside. It should also be noted that the metal charge of this crucible (copper, arsenic, and lead combined) differs markedly from that of the other smelting or melting crucibles from Tepe Hissar (all found on the Main Mound), which generally contain lowlevel copper-arsenic alloys. ${ }^{1}$

The presence of an inner slag layer with high amounts of lead and copper oxides in a vitrified siliceous matrix clearly identify this as a metallurgical crucible. The close compositional similarity between the siliceous matrix of the slag (S66a-L1) and the underlying ceramic (S66a-L2), and the high amount of lead oxide in both layers, demonstrate that the metallurgical process was carried out inside the crucible but under oxidising conditions. Ore smelting would likely involve a more reducing atmosphere and leave behind a much more iron-rich slag, as demonstrated by the composition of the nearby copper smelting slag (S120), which has $50 \mathrm{wt} \%$ iron oxide and less than $1 \mathrm{wt} \%$ magnesia. Instead, the evidence points to the melting of a copper-lead alloy containing relatively high levels of silver and arsenic. $^{2}$ Whether this was simply for casting or as part of another operation, such as fire refining or alloying, cannot be deduced at present.

The identification of the melting of a lead-rich alloy under oxidizing conditions is significant for the interpretation of the observed vitrification pattern in this crucible, which has a fully vitrified slag inside and a highly vitrified outer surface, but shows little vitrification of the central, white layer. As outlined above, Chalcolithic and Bronze Age crucibles were generally heated from above, resulting in a strong vitrification of the inner surface, but hardly any alteration of the outer surface. Firing metallurgical crucibles from the outside or below, as indicated for this crucible by the strong outer vitrification, is only known from the Iron Age onward, and would result in a continuous vitrification throughout the fabric of the vessel.

On first sight, the crucible shows two opposing vitrification trends. One runs through the outer chaffy layer, indicating a higher temperature for the outer parts compared to the inner section as one would expect from an externally-fired vessel. The other runs through the inner, more vitrified slag layer into the white ceramic and thus seems to indicate higher temperature inside. This pattern could be the result of simultaneously heating the crucible from the outside and inside. However, the change in apparent vitrification at the boundary between layers 2 and 3 makes it clear that the dissimilar degrees of vitrification are due to the different chemical and mineralogical make-up of the various layers, and do not represent differing temperature gradients. Thus, we argue that this pattern is due to heating of a complex vessel from the outside only.

The visual appearance of Layers 2 and 3 demonstrates the stark difference in vitrification behaviour or refractoriness between the white magnesia-rich ceramic (S66a-L2) and the chaffy outer ceramic (S66a-L3). In order to quantify the different vitrification temperatures of the two materials, we compared the average bulk compositions to ternary diagrams outlining the liquidus temperatures of the systems $\mathrm{SiO}_{2}-\mathrm{MgO}-\mathrm{CaO}$ and $\mathrm{SiO}_{2}-\mathrm{Al}_{2} \mathrm{O}_{3}-\mathrm{CaO}$,

\footnotetext{
${ }^{1}$ Interestingly, copper-lead production slags were found on the South Hill of Tepe Hissar, but they were all furnace slags. There is at present no evidence for the use of crucibles on the South Hill, and little evidence for the production of arsenical copper in this same area.

2 The relative proportion of lead oxide and copper oxide is not representative of the original metal charge. Lead metal is significantly less noble than copper, and under oxidising conditions will oxidise preferentially, strongly enriching the resulting slag. However, the presence of lead prills trapped within the cracks of the crucible indicates that the melt did contain sufficient lead metal to form a separate melt phase.
} 
Table 2

SEM-EDS area analyses of stratified technical ceramics from Tepe Hissar separated by location (Main Mound (MM) and South Hill (SH)) and by date.

\begin{tabular}{|c|c|c|c|c|c|c|c|c|c|c|c|c|}
\hline Sample & Date & $\mathrm{Na}_{2} \mathrm{O}$ & $\mathrm{MgO}$ & $\mathrm{Al}_{2} \mathrm{O}_{3}$ & $\mathrm{SiO}_{2}$ & $\mathrm{P}_{2} \mathrm{O}_{5}$ & $\mathrm{SO}_{3}$ & $\mathrm{~K}_{2} \mathrm{O}$ & $\mathrm{CaO}$ & $\mathrm{TiO}_{2}$ & $\mathrm{FeO}$ & $\mathrm{CuO}$ \\
\hline MS161bCer* & ca. 3600 & 1.1 & 3.2 & 13.8 & 57.2 & 0.1 & 0.1 & 3.2 & 14.5 & 0.8 & 5.9 & 0.1 \\
\hline MS161cCer & ca. 3600 & 1.0 & 2.4 & 13.5 & 60.2 & 0.0 & 0.2 & 2.9 & 13.1 & 0.8 & 5.6 & 0.0 \\
\hline S63bCer & ca. 3500 & 1.2 & 5.8 & 9.6 & 59.8 & 0.0 & 0.0 & 1.9 & 13.3 & 0.7 & 4.8 & 3.0 \\
\hline S48Cer & ca. 3300 & 1.4 & 2.8 & 13.6 & 59.9 & 0.4 & 0.2 & 2.8 & 12.2 & 0.9 & 5.4 & 0.1 \\
\hline $\mathrm{N} 28, \mathrm{~m}$ & ca. 3200 & 1.7 & 2.8 & 14.6 & 52.9 & 0.3 & 3.9 & 5.1 & 12.0 & 0.8 & 5.3 & 0.0 \\
\hline S22 & ca. 3200 & 1.4 & 3.4 & 15.5 & 54.8 & 0.0 & 0.0 & 2.7 & 15.1 & 0.9 & 6.0 & 0.0 \\
\hline S40aCer & ca. 3000 & 1.2 & 2.9 & 12.6 & 60.1 & 0.2 & 0.0 & 2.4 & 14.2 & 0.8 & 5.0 & 0.0 \\
\hline S47aCer* & ca. 3000 & 1.4 & 3.4 & 10.6 & 49.5 & 1.9 & 1.0 & 3.9 & 21.3 & 0.7 & 6.4 & 0.0 \\
\hline S47bCer* & ca. 3000 & 1.6 & 1.9 & 11.0 & 46.8 & 1.9 & 7.0 & 1.8 & 13.0 & 0.7 & 5.6 & 7.3 \\
\hline S47dCer & ca. 3000 & 1.3 & 2.4 & 11.1 & 65.1 & 1.3 & 0.2 & 1.5 & 11.8 & 0.6 & 4.4 & 0.0 \\
\hline S41aCer* & ca. 2900 & 0.0 & 3.4 & 9.3 & 60.9 & 0.8 & 0.8 & 2.8 & 10.2 & 0.6 & 8.2 & 2.3 \\
\hline S41bCer & ca. 2900 & 1.8 & 2.9 & 13.9 & 59.4 & 0.6 & 0.0 & 1.8 & 13.1 & 0.8 & 5.3 & 0.0 \\
\hline MM Aver & & 1.3 & 3.1 & 12.4 & 57.2 & 0.6 & 1.1 & 2.7 & 13.7 & 0.8 & 5.7 & \\
\hline h76-5Cer & ca. 3200 & 1.6 & 2.6 & 12.6 & 60.6 & 0.9 & 0.0 & 1.8 & 13.8 & 0.7 & 4.9 & 0.0 \\
\hline h76-10Cer & ca. 3200 & 1.7 & 2.5 & 11.4 & 59.7 & 0.6 & 0.4 & 2.0 & 15.3 & 0.7 & 5.0 & 0.0 \\
\hline MS170bCer* & ca. 3200 & 1.2 & 2.9 & 13.8 & 57.4 & 0.0 & 0.0 & 2.7 & 14.4 & 0.8 & 5.6 & 1.0 \\
\hline MS132aCer* & ca. 3200 & 1.2 & 1.6 & 8.3 & 68.6 & 1.0 & 0.2 & 1.3 & 11.0 & 0.7 & 4.4 & 0.2 \\
\hline MS131dCer* & ca. 3200 & 0.9 & 2.9 & 11.2 & 58.5 & 0.2 & 0.1 & 2.7 & 18.4 & 0.7 & 4.2 & 0.2 \\
\hline h76-15Cer & ca. 2900 & 1.5 & 3.3 & 12.9 & 55.2 & 1.2 & 0.7 & 1.4 & 16.8 & 0.9 & 6.0 & 0.0 \\
\hline $\mathrm{S} 91, \mathrm{~m}$ & ca. 2900 & 0.9 & 3.1 & 13.7 & 58.2 & 0.3 & 0.1 & 3.2 & 14.0 & 0.8 & 5.0 & 0.0 \\
\hline SH Aver & & 1.3 & 2.7 & 12.0 & 59.7 & 0.6 & 0.2 & 2.2 & 14.8 & 0.8 & 5.0 & \\
\hline S66a-L3 & ca. 3600 & 2.5 & 2.6 & 11.8 & 58.9 & - & 0.2 & 2.4 & 15.2 & 0.8 & 4.8 & 0.0 \\
\hline
\end{tabular}

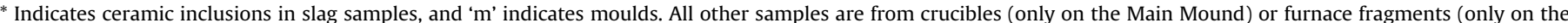

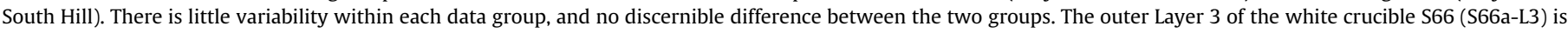

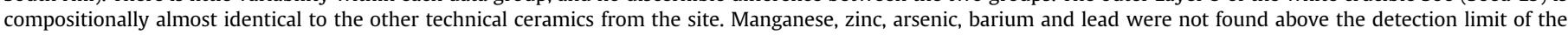
instrument, estimated to be in the range of $0.2 \mathrm{wt} \%$. Data is normalised to $100 \mathrm{wt} \%$.

respectively. To do so, we reduced the number of oxides in each material to three by combining suitable groups of oxides (adding alumina to silica and iron oxide to lime in the white ceramic, and adding magnesia and iron oxide to lime for the chaffy ceramic) and re-normalised the three reduced oxides to $100 \mathrm{wt} \%$. The position of the resulting data points in the ternary diagrams indicates a liquidus temperature of $1600-1700{ }^{\circ} \mathrm{C}$ for the white ceramic, and around $1200{ }^{\circ} \mathrm{C}$ for the chaffy ceramic. (Figs. 15 and 16)

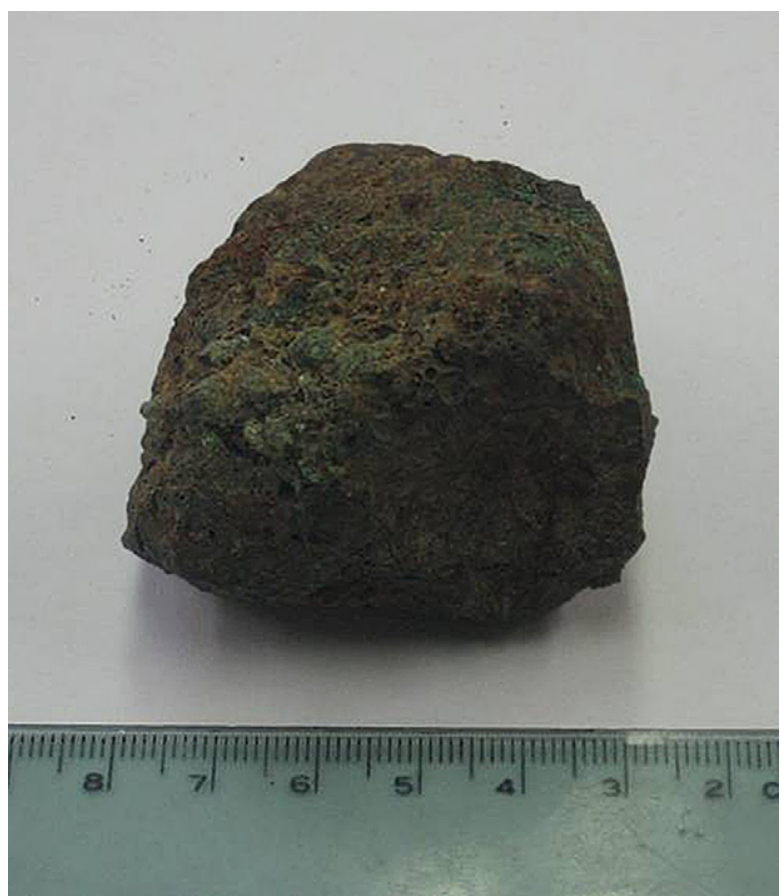

Fig. 12. Photograph of the slag (S120) found together with the crucible discussed here at the bottom of the 1976 test trench on the North Flat at Tepe Hissar. Note the large, massive form of this iron-rich and heavy slag, which is unlikely to have been produced in the small crucibles usually associated with Chalcolithic smelting practices.
These temperatures cannot be taken at face value, however, as they represent only pure three-component systems and complete vitrification. The presence of several further oxides in concentrations of a few weight percent each will considerably reduce the effective temperatures, probably by one or two hundred degrees centigrade. Also, complete vitrification is not reached in these ceramics; instead, we have to look at the eutectic melting temperatures - i.e., those for the lowest-melting compositions. For the chaffy ceramic, this indicates considerable vitrification taking place already at around $1000^{\circ} \mathrm{C}$. For the white ceramic, the eutectic temperature for the pure system is above $1300^{\circ} \mathrm{C}$, and for the real system probably still above $1200^{\circ} \mathrm{C}$.

The complete vitrification of the slag on the interior of the crucible is strongly promoted by the presence of lead oxide,

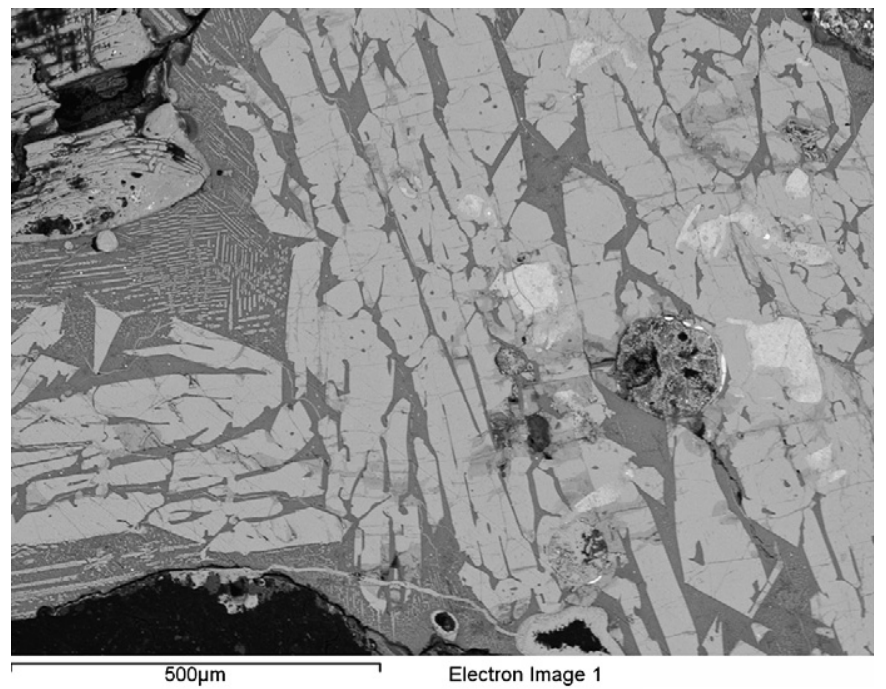

Fig. 13. Backscattered electron image showing large fayalite crystals and few iron spinels in the exterior surface area of the slag (S120), in which charcoal fragments still embedded in the slag led to strongly reducing conditions. 


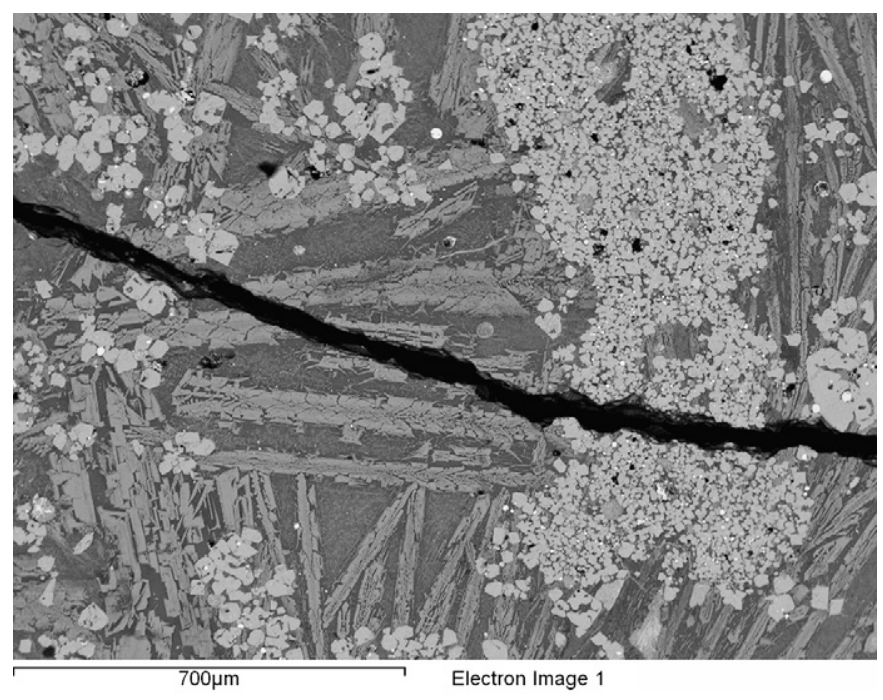

Fig. 14. Backscattered electron image showing fayalite chains and clusters of iron spinels in the interior of the slag (S120). Small prills of copper sulphide and copperarsenic can be found amongst the iron oxide phases, suggesting perhaps the smelting of copper-arsenic ores in an iron-rich matrix (e.g., haematite) or the mixing of copper ores with iron (-arsenic?) sulphide ores.

a powerful flux for siliceous materials. As discussed above, the crucible slag was formed from the reaction of the white layer material with additional lead (and copper) oxide, indicating that the conditions within the crucible were at least slightly oxidising. No suitable liquidus diagram for $\mathrm{MgO}-\mathrm{SiO}_{2}-\mathrm{PbO}$ was found in the literature; however, inspection of the nearest cross-section in the system 2PbO.MgO.2SiO $2-\mathrm{MgO} . S i O_{2}$ (Phase Diagrams for Ceramicists II, 2513-2518) suggests that the liquidus temperature of this slag might have been as low as $800^{\circ} \mathrm{C}$.

Thus, we see a strong chemical diversity across the body of the crucible, with a low-melting slag composition inside, followed by a highly refractory white layer in the middle which constituted the crucible proper, and an outer layer of much less refractory chaffy ceramic. Heating this composite crucible from the outside would have produced a relatively flat thermal gradient through the body of the vessel. However, the different chemical compositions resulted in vastly different vitrification degrees, from a fully molten slag inside, through a strongly vitrified and softened outer layer, to the hardly vitrified central part.

The white ceramic of Layer 2 does not consist of pure steatite, but of a mixture of steatite and ordinary calcareous clay. A rough mass balance estimation, using the average composition of the local technical ceramic and an idealised composition of pure steatite taken from the literature, indicates that a mixture of about $60 \mathrm{wt} \%$ steatite and $40 \mathrm{wt} \%$ ordinary local clay would result in a bulk composition very similar to the bulk composition of the white layer (Table 3).

\section{Discussion}

The data presented above allow for a tentative reconstruction of how this unusual crucible was made and used. The first step was undoubtedly the collection of steatite from one of the many local sources located roughly $80-100 \mathrm{~km}$ south of Hissar in the Elburz Mountains. According to the field notes of Vincent Pigott, evidence for the working of soft stone (steatite or chlorite) was found in association with the very earliest slags and crucible fragments

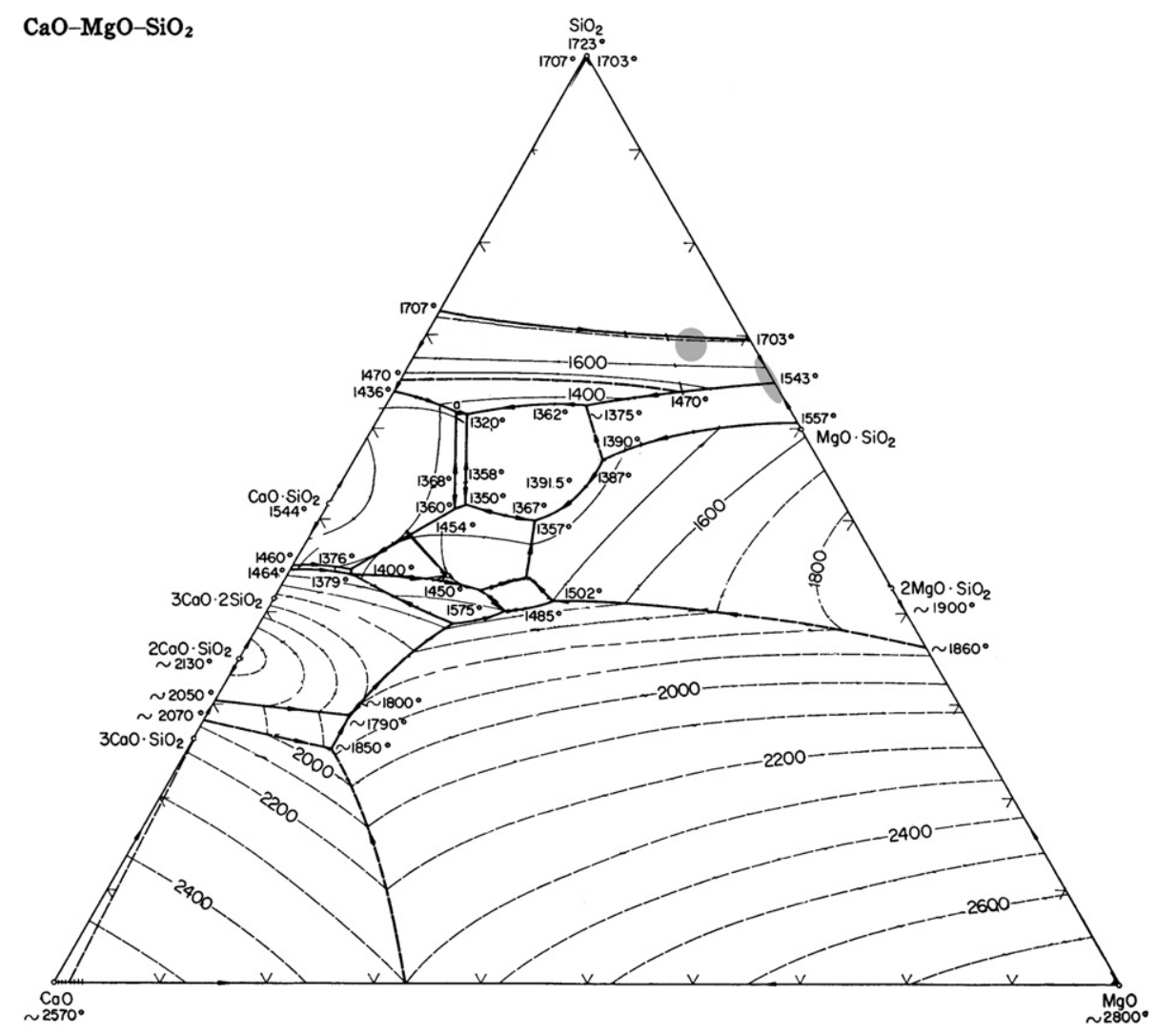

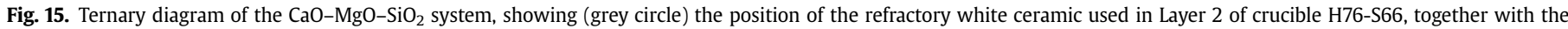

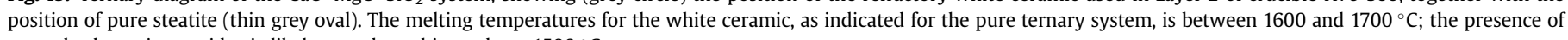
several other minor oxides is likely to reduce this to about $1500^{\circ} \mathrm{C}$. 


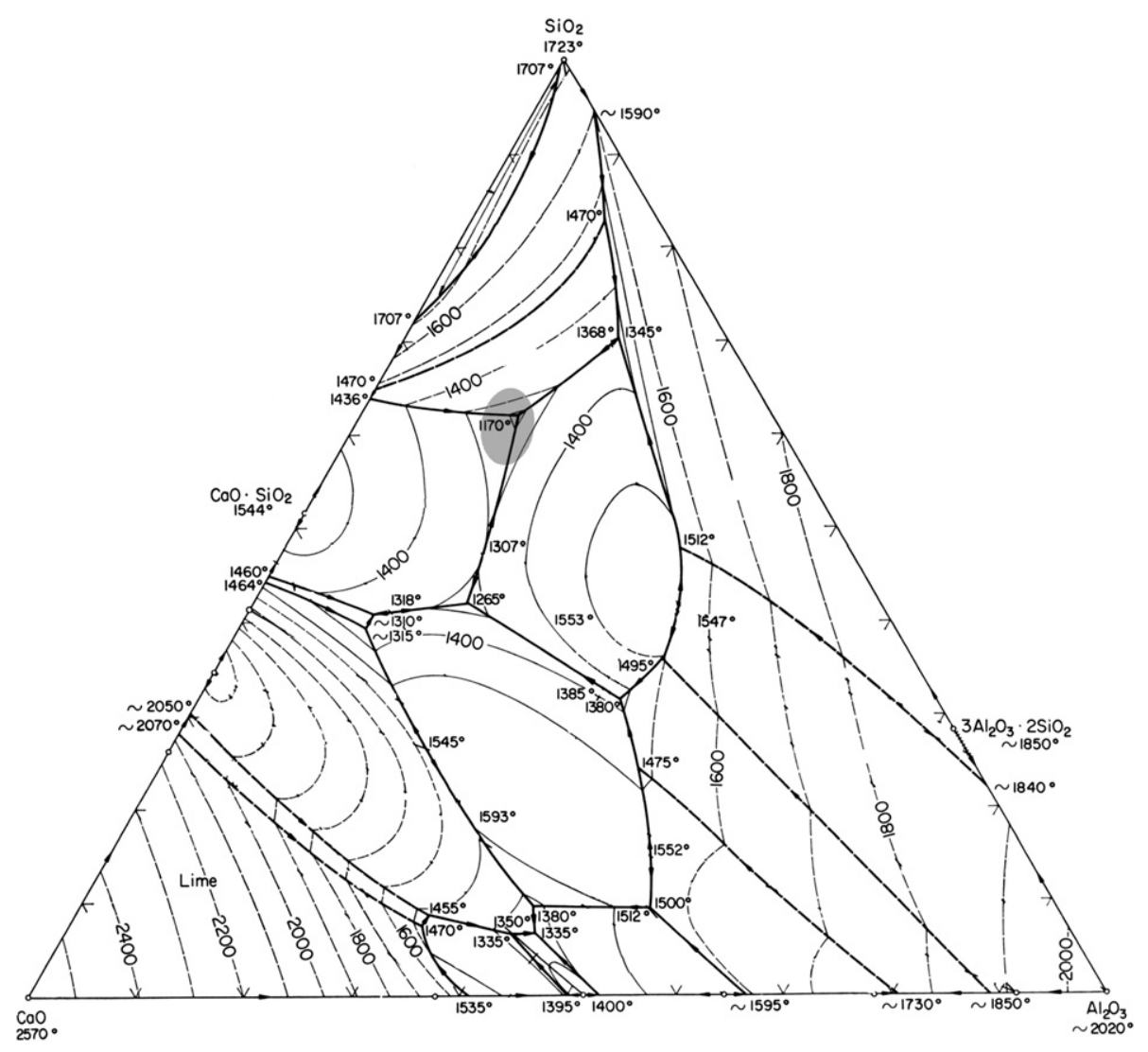

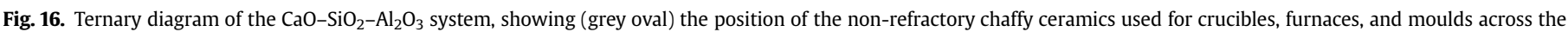

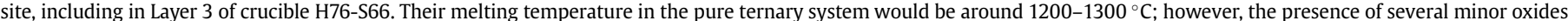
in the real ceramic is likely to bring this down considerably.

(H76-MS161) from the Main Mound (context: CG90 DS lot 8), roughly contemporary with the crucible discussed here. It is also worth noting that in their survey of Iranian copper ore sources, Bazin and Hübner (1969) mention at least two mining regions in Northeast Iran (Kuh-e Zar near Torud and Taknar in Khorassan) in which copper ores are found in complex matrices of quartz and chlorite/steatite gangue, often in association with other valuable resources such as turquoise, gold, lead ores, and copper arsenides.

\subsection{Building the crucible}

With the steatite in hand, the craftsperson would then have crushed it into a fine powder and mixed it with the local calcareous clay and an abundance of short organic temper, before carefully moulding the resulting paste (presumably by hand) to its final shape. It is worth noting here that it is impossible to say whether this white ceramic was fired before it was used as a metalworking crucible, although the well-finished rim, the presence of iron oxide painted onto the exterior surface, and the fact that wet slabs of coarse chaffy ceramic were slapped onto this same surface, may suggest at least a preliminary firing of the white ceramic to provide some stability. The addition of iron oxide to the exterior surface could have had symbolic significance, or was potentially used to superficially flux the white ceramic during firing and perhaps also to flux the inner surface of the chaffy ceramic slabs in order to fuse the two types of ceramic together.

Petrographic investigation showed that the steatite fragments were not only thermally refractory, but also rendered the fabric rather brittle (see Fig. 4). The individual fragments of steatite in Layer 2 were held together only by a matrix of heavily vitrified ceramic of a composition very similar to the chaffy ceramic used for the outside. This brittleness would have made handling of the crucible, such as for casting, fraught with the danger of breakage. Applying the outer layer of thick chaffy ceramic would counteract this. The downside of adding this outer layer - i.e., slowing down the heat flow into the crucible and hence requiring prolonged heating to melt the charge - would have been noticeable. However, the limited thermal conductivity of the crucible would

Table 3

Mass balance estimation of the white layer in crucible S66a.

\begin{tabular}{|c|c|c|c|c|c|c|c|c|c|}
\hline Sample & $\mathrm{Na}_{2} \mathrm{O}$ & $\mathrm{MgO}$ & $\mathrm{Al}_{2} \mathrm{O}_{3}$ & $\mathrm{SiO}_{2}$ & $\mathrm{~K}_{2} \mathrm{O}$ & $\mathrm{CaO}$ & $\mathrm{TiO}_{2}$ & $\mathrm{FeO}$ & $\mathrm{CuO}$ \\
\hline Steatite & & 33.0 & 1.0 & 65.0 & & & & 1.0 & \\
\hline $\begin{array}{c}\text { Average TC } \\
60: 40\end{array}$ & 1.3 & 2.9 & 12.2 & 58.5 & 2.5 & 14.2 & 0.8 & 5.4 & 0.2 \\
\hline Steatite:TC & 0.5 & 21.0 & 5.5 & 62.4 & 1.0 & 5.7 & 0.3 & 2.2 & 0.1 \\
\hline S66a_L2* & 2.0 & 20.3 & 3.8 & 62.9 & 1.5 & 6.2 & 0.1 & 2.1 & 0.7 \\
\hline
\end{tabular}

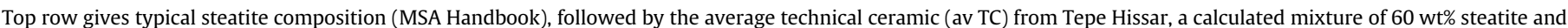
$40 \mathrm{wt} \%$ average technical ceramic, and the white layer as analysed, re-normalised from Table 1 without lead oxide (S66a_L2*). All data presented in wt\%. 
also have reduced cooling of the vessel when it was removed from the fire for casting, thus giving the craftsperson an extra couple of seconds before the metal would start to consolidate.

\subsection{Using the crucible}

Once the crucible was prepared, a charge probably consisting of copper-arsenic metal and lead metal was placed inside. The copper may have been produced locally by another operation, represented on site by the single piece of furnace slag (S120) described above and others not here reported. The crucible was then probably placed in a small bowl-furnace containing charcoal or possibly dung as fuel. The slightly elevated amounts of $\mathrm{PbO}$ throughout the entire crucible, but most especially in the slag, suggest an oxidising environment inside the crucible.

The mode of heating of this crucible is of major interest. As outlined above, most Bronze Age crucibles are comprised of a rather thick non-refractory technical ceramic and were fired from above/inside. The insulating properties and design features of the ceramics, such as wall thickness and organic temper, make this feasible even if total vitrification of the inner surface occurs. We are not aware of any other metallurgical crucible before ca. $500 \mathrm{BC}$ that was heated from below/outside, as is indicated for H76-S66 by the massive vitrification of the outer layer.

Above, we argue that this crucible was heated from the outside only, resulting in a very gentle thermal gradient from the outer surface, which was in direct contact with the fuel, sloping towards the inside of the crucible where the metal was melted. Quantifying this temperature is difficult; above, we have estimated the vitrification temperature for the chaffy ceramic to be around $1000^{\circ} \mathrm{C}$. This would be in good agreement with the temperature required to melt a copper alloy containing several percent each of arsenic and lead. Depending on composition, partial melting in this system starts well below $800^{\circ} \mathrm{C}$, and complete fusion at around $1000^{\circ} \mathrm{C}$. The presence of lead oxide not only in the crucible slag, but permeating deeply into the fabric of the crucible, indicates rather oxidising conditions inside the vessel. One would expect such conditions for a crucible in which the fuel was no longer part of the charge, and thus would not provide more reducing conditions. We mentioned the possibility of heating from both the interior and exterior, thereby resulting in a similar vitrification pattern. However, the oxidising conditions inside the crucible, and the absence of any significantly enhanced concentrations of typical fuel ash oxides such as potash and lime in the crucible slag (see Table 1), suggest that no fuel was burnt inside the vessel.

\subsection{Understanding the crucible}

It has to be asked why the metalworker created such a complex and (in its handling) unusual tool, and why they did not continue doing so. The analysis of the crucible indicates that the metal charge was arsenical copper relatively rich in lead. One reason to use this unusual design may have been the large variability in temperature and redox conditions within an internally-fired crucible, due to the pulsed and very localised nature of the air flow from blowpipes. Such uncontrolled conditions may have led to excessive loss of lead and arsenic metal from the alloy in those parts of the charge which received particularly high temperatures and oxidising conditions in front of the blowpipes. Arsenic would be lost as vapour $\left(\mathrm{As}_{2} \mathrm{O}_{3}\right)$ while lead would convert to lead oxide which then immediately reacts with the hot ceramic, forming lead silicates and severely eroding the crucible fabric. Thus, another possible reason for the development of this crucible design may lie in the rather corrosive action of lead oxide on normal ceramics.
While the talc-rich material in H76-S66 has also been attacked, as is evident from the composition of the crucible slag, it is likely to have reacted much less strongly than the fabric of crucibles made of calcareous clay, due to the much higher thermal and chemical refractoriness of steatite.

Alternatively, or in addition, the development of noxious fumes rich in arsenic and lead may have been too much even for the seasoned metalworkers of the Late Chalcolithic to tolerate. Using an externally-heated crucible would provide a much more stable and homogenous chemical and thermal environment within the vessel, limiting the evaporation of lead and arsenic. Work is in progress to test whether any of the other crucibles from the site, made from ordinary calcareous technical ceramic and clearly heated from above, were used to process a similar alloy. At present, none of the ordinary crucibles show in their vitrified parts lead or arsenic oxide concentrations above the detection limits of the SEM-EDS system, even when high levels of copper, arsenical copper or copper oxide are present (see Table 2). There are, however, slags from the beginning of the third millennium that demonstrate the mixed smelting of copper-arsenic-lead alloys. This fact indicates an obvious change in the metallurgical processes being performed at Tepe Hissar, but is outside the remit of this paper (see Thornton, 2009).

Several reasons may have contributed to the demise of this elaborate crucible technology. For example, an increase in metal demand and production in the second half of the 4th millennium may have facilitated the use of furnaces with their generally different mass flow system (Rehren, 2003), and would also have required too large quantities of the talc/steatite to maintain such an advanced technology. Similarly, a change in metal production techniques could have led to the utilization of a different ore source - one not near to a steatite source - and with the shift to imported lapis lazuli working by the late 4 th millennium, perhaps steatite sources were no longer so heavily utilized. Alternatively, the cessation of talc-based ceramics may have been the result of a sudden loss of knowledge, possibly the death of a particularly innovative crucible maker. Another possibility is that the technology was not lost at all, but that simply insufficient studies of technical ceramics have been conducted to identify other examples of these composite crucibles. What is clear is that the single crucible, from which we have several fragments, was made by a highly-skilled craftsperson with significant understanding of the properties of ceramics, steatite and possibly 'talc-faience' (for the latter, see McCarthy and Vandiver, 1991). This crucible was not a mistake or an experimental product - it was a well thought-out and highly-specialized tool for a specific purpose. As such, there must have been a tradition leading to its production and use, and other examples should be sought in this region.

\section{Conclusion}

Linear models of technological evolution that attempt to state when certain techniques and materials 'must have been' invented have long been discredited (e.g., Heskel and Lamberg-Karlovsky, 1980). While this crucible is currently unique, it serves to reemphasize that technical knowledge may appear and disappear many times before it is finally adopted on a wide scale (if at all). It is also important to remember that technological innovation does not emerge from a vacuum, but is often the product of multiple technologies being performed by a particularly imaginative craftsperson, or of multiple specialized craftspeople coming together for a common purpose. There is no question that this early refractory crucible was the work of a professional craftsperson who was quite familiar with ceramic, steatite, and metal technologies. Indeed, the presence of ore gangue inside the white ceramic (Layer 2) suggests 
that the talc-based ceramic was made using debris collected from a workshop where both steatite and copper minerals were mechanically worked. Such mineral processing, producing a paste of crushed steatite with a clay binder and water, is known from Chalcolithic beads from the Peqi'in cave in Israel and elsewhere, including Mesopotamia, India and Pakistan (Bar-Yosef Mayer et al., 2004, and literature therein)

While this inherently "multi-craft" artefact is significant for what it can tell us about relations between crafts in prehistory and the non-linear development of ancient technologies, this crucible is also important for those who study the history of steatite-based crafts in this region (see Moorey, 1994: 168-173; Vidale, 2000: 5866; Miller, 2007: 209-212). Beginning in the 6th millennium BCE with the firing of steatite beads to turn them first black and then white (at temperatures above $\sim 700^{\circ} \mathrm{C}$ ), to the glazing of steatite and eventual production of talc-faience from Egypt to India in the $4^{\text {th }}$ millennium BCE, the manipulation of (and application of heat to) steatite and its relation to copper-based glazes has been relatively well-studied, particularly in the Indus Valley and hinterlands of Pakistan. However, few examples have been noted from prehistoric Iran, and to our knowledge not a single example of a steatite-based ceramic vessel has ever been recorded from the Middle East. What relation this crucible has to the development of steatite-based arts is a subject for future study.

Finally, the presence of a single refractory crucible used by a metalworker in Northeast Iran nearly three thousand years before refractory crucibles were widely adopted does not in itself significantly change our understanding of the development of refractory technical ceramics, nor does it really alter our interpretation of prehistoric metallurgy. Instead, this crucible is important because it proves that at the critical junction between the Late Chalcolithic and the Early Bronze Age, the knowledge of how to produce a truly refractory crucible that could be heated from the exterior existed. Furthermore, this crucible existed at a modest-sized town in which non-refractory melting crucibles, similar to those analyzed from a number of contemporary sites across the Middle East, were in use both concurrently and for the next 500 years or so.

In other words, non-refractory metalworking crucibles were not made because they were the only available option, but because they were actively selected by early metalworkers. Whether these chaffy ceramics made of calcareous clays were chosen due to some beneficial 'sacrificial' qualities, or simply because they were sufficient for the task at hand and cheaper and easier to make, is a question that requires future study. Clearly, specialized ceramic materials were known and used elsewhere during the $4^{\text {th }}$ millennium BCE, such as cupellation hearth linings in Mesopotamia which were similarly chosen for their chemical refractoriness against lead oxide (Pernicka et al., 1998). However, until more such crucibles are discovered and analyzed, we must simply accept the fact that the knowledge base for the production of technical ceramics was much wider than previously expected, and we must come to understand the implications of this for studies of pyrotechnology in Southwest Asia.

\section{Acknowledgements}

All analyses were carried out at the Wolfson Archaeological Science Laboratory at the UCL Institute of Archaeology. We wish to thank Simon Groom, Sandra Bond, James Hales and Kevin Reeves for their assistance with the analyses presented herein. Robert $\mathrm{H}$. Dyson Jr. and Vincent Pigott provided important information about the archaeological context of the site as well as the samples for analysis. The University of Pennsylvania Museum is thanked for allowing access to the crucible fragments. CPT acknowledges financial support from the European Union, Marie Curie EST Action
Science and Conservation in Archaeology, Contract MEST-2004519504, for a three-month fellowship at the UCL Institute of Archaeology in 2006.

\section{References}

Bar-Yosef Mayer, D.E., Porat, N., Gal, Z., Shalem, D., Smithline, H., 2004. Steatite beads at Peqi'in: long-distance trade and pyro-technology during the Chalcolithic of the Levant. Journal of Archaeological Science 31, 493-502.

Bayley, J., Rehren, Th., 2007. Towards a functional and typological classification of crucibles. In: La Niece, S., Hook, D., Craddock, P.T. (Eds.), Metals and Mines Studies in Archaeometallurgy. Archetype, London, pp. 46-55.

Bazin, D., Hübner, H., 1969. Copper Deposits in Iran. Geological Survey of Iran, Tehran. Report 13

Caldwell, J.R., 1968. Tal-I-Iblis and the beginning of copper metallurgy at the fifth millennium. Archaeologia Viva 1, 145-150.

Davey, C., 1985. Crucibles in the Petrie collection and hieroglyphic ideograms for metal. Journal of Egyptian Archaeology 71, 142-148.

Davey, C., 1988. Tell Edh-Dhiba'i and the southern Near Eastern metalworking tradition. In: Maddin, R. (Ed.), The Beginnings of the Use of Metals and Alloys. MIT Press, Cambridge, MA, pp. 63-68.

Dyson Jr., R.H., Howard, S.M. (Eds.), 1989. Tappeh Hesar: Reports of the Restudy Project, 1976. Case Editrice le Lettere, Firenze.

Dyson Jr., R.H., Lawn, B., 1989. Key stratigraphic and radiocarbon elements for the 1976 Hesar sequence. In: Dyson Jr., R.H., Howard, S.M. (Eds.), Tappeh Hesar: Reports of the Restudy Project, 1976. Case Editrice le Lettere, Firenze, p. 143.

Dyson Jr., R.H., Remsen, W.C., 1989. Observations on architecture and stratigraphy at Tappeh Hesar. In: Dyson Jr., R.H., Howard, S.M. (Eds.), Tappeh Hesar: Reports of the Restudy Project, 1976. Case Editrice le Lettere, Firenze, pp. 69-110.

Eckert, H.E., 1990. Der Gelbguss nach dem Wachsausschmelzverfahren bei den Senufo in West-Afrika. Der Anschnitt 42, 46-53.

Frame, L.D., 2004. Investigations at Tal-i Iblis: Evidence for Copper Smelting during the Chalcolithic Period. B.S. thesis. Department of Material Science and Engineering, Massachusetts Institute of Technology.

Freestone, I., 1989. Refractory materials and their procurement. In: Hauptmann, A., Pernicka, E., Wagner, G. (Eds.), Old World Archaeometallurgy. Der Anschnitt, Beiheft 7. Deutsches Bergbau-Museum, Bochum, pp. 155-162.

Heskel, D.L., Lamberg-Karlovsky, C.C., 1980. An alternative sequence for the development of metallurgy: Tepe Yahya, Iran. In: Wertime, T., Muhly, J. (Eds.), The Coming of the Age of Iron. Yale University Press, New Haven, pp. 229-266.

Lamberg-Karlovsky, C.C., 1974. Historical continuity, stage and process: the development of a metallurgical technology. In: Ghosh, A.K. (Ed.), Perspectives in Palaeoanthropology: D. Sen Festschrift. Firma K.L. Mukhopadhyay, Calcutta, pp. 331-344.

Matinón-Torres, M., Freestone, I., Hunt, A., Rehran, Th., 2008. Mass-produced mullite crucibles in medieval Europe: manufacture and material properties. Journal American Ceramic Society 91, 2071-2074.

McCarthy, B., Vandiver, P.B., 1991. Ancient High-Strength Ceramics: Fritted Faience Bracelet Manufacture at Harappa (Pakistan), ca. 2300-1800 B.C. In: Vandiver, P.B., Druzik, J., Wheeler, G.S. (Eds.), Materials Issues in Art and Archaeology II: Symposium Held April 17-21, 1990. Materials Research Society Symposium Proceedings, vol. 185. Materials Research Society, Pittsburgh, pp. 495-510.

McGovern, P.E., Notis, M.D. (Eds.), 1989. Ceramics and Civilization IV: Cross-craft and Cross-cultural Interactions in Ceramics. American Ceramic Society, Inc, Westerville, $\mathrm{OH}$.

Miller, H.M.-L., 2007. Archaeological Approaches to Technology. Elsevier Inc, San Diego.

Moorey, P.R.S., 1994. Ancient Mesopotamian Materials and Industries: the Archaeological Evidence, second ed. Eisenbrauns, Winona Lake, Indiana [1999].

Neuninger, H., Pittioni, R., Siegel, W., 1964. Frühkeramikzeitliche Kupfergewinnung in Anatolien. Archaeologia Austriaca 35, 98-110.

Oberweiler, C., 2005. La métallurgie du cuivre et du bronze dans le monde égéen du Bronze Ancien au début du Bronze Récent (IIIe millénaire - début du Ile millénaire av. J.-C.): les techniques de fonderie. Ph.D. dissertation, University of Paris I, Panthéon Sorbonne.

Ottaway, B.S., Roberts, B.W., 2008. The emergence of metalworking. In: Jones, A (Ed.), Prehistoric Europe: Theory and Practice. Blackwell, London.

Pernicka, E., Rehren, Th., Schmitt-Strecker, S., 1998. Late Uruk silver production by cupellation at Habuba Kabira, Syria. In: Rehren, Th., Hauptmann, A., Muhly, J. (Eds.), Metallurgica Antiqua, In Honour of Hans-Gert Bachmann and Robert Maddin. Deutsches Bergbau-Museum, Bochum, pp. 123-134.

Rehren, Th., 1997. Tiegelmetallurgie: Tiegelprozesse und ihre Stellung in der Archäometallurgie., Habilitation thesis. TU Bergakademie Freiberg.

Rehren, Th., 2003. Crucibles as reaction vessels in ancient metallurgy. In: Craddock, P.T., Lang, J. (Eds.), Mining and Metal Production Through the Ages. British Museum Press, London, pp. 147-149. and 207-215.

Rehren, Th., Hess, K., Phillip, G., 1997. Fourth millennium BC copper metallurgy in northern Jordan: the evidence from Tell esh-Shuna. In: Gebel, H., Kafafi, Z., Rollefson, G. (Eds.), The Prehistory of Jordan II, Perspectives from 1997. Studies 
in Early Near Eastern Production, Subsistence, and Environment, 4. Ex Oriente, Berlin, pp. 625-640.

Schmidt, E.F., 1937. Excavations at Tepe Hissar: Damghan. University Museum, Philadelphia.

Schwedt, A., Mommsen, H., Zacharias, N., Buxeda, J., 2006. Analcime crystallization and compositional profiles - comparing approaches to detect post-depositional alterations in archaeological pottery. Archaeometry 48, 237-251.

Shimada, I., 1996. Sican metallurgy and its cross-craft relationship. Boletin Museo del Oro 41, 27-62.

Shimada, I., 2007. Craft Production in Complex Societies: Multicraft and Producer Perspectives. University of Utah Press, Salt Lake City.

Thornton, C.P., 2009. The Chalcolithic and Early Bronze Age Metallurgy of Tepe Hissar, Northeast Iran: A Challenge to the Levantine Paradigm. Ph.D. thesis, Department of Anthropology, University of Pennsylvania.

Thornton, C.P., Rehren, Th., Pigott, V.C., 2009. The production of speiss (iron arsenide) during the Early Bronze Age in Iran. Journal of Archaeological Science 36, 308-316.
Tite, M.S., Hughes, M.J., Freestone, I.C., Meeks, N.D., Bimson, M., 1990. Technological characterisation of refractory ceramics from Timna. In: Rothenberg, B. (Ed.), The Ancient Metallurgy of Copper. UCL Institute for Archaeo-Metallurgical Studies, London, pp. 158-175.

Tosi, M., 1984. The notion of craft specialization and its representation in the archaeological record of early states in the Turanian Basin. In: Spriggs, M. (Ed.) Marxist Perspectives in Archaeology. Cambridge University Press, Cambridge, pp. 22-52.

Tosi, M. 1989. The distribution of industrial debris on the surface of Tappeh Hesar as an indication of activity areas. In: Dyson Jr., R.H., Howard, S.M. (Eds.), Tappeh Hesar: Reports of the Restudy Project, 1976. Case Editrice le Lettere, Firenze, pp. $13-24$.

Veldhuijzen, A.H., Rehren, Th., 2007. Slags and the city: early iron production at Tell Hammeh, Jordan, and Tel Beth-Shemesh, Israel. In: LaNiece, S., Hook, D. Craddock, P. (Eds.), Metals and Mines - Studies in Archaeometallurgy. Archetype, London, pp. 189-201.

Vidale, M., 2000. The Archaeology of Indus Crafts. IsIAO, Rome. 